\title{
ECSETVONÁSOK LUKÁCS GYÖRGY PÁLYAKÉPÉHEZ
}

Fekete Éva Lukács Györgyről szóló monográfiája (mely eredetileg 1974-ben készült el) nagyszabású és igen értékes vállalkozás. Ahogy a kötet alcíme is mutatja, egy hátramaradt kézirat gondos szerkesztői munkával sajtó alá rendezett, posztumusz kiadásáról van szó. A kötet számos aspektusból közelíthető meg és elemezhető, de itt elsősorban a mü újszerüségét szeretném bemutatni, az eddig napvilágot látott monográfiákhoz képest.

Mindeddig igen kevés szisztematikus és komplex, Lukács egész életére és munkásságára fókuszáló mủ látott napvilágot; s e könyvek esetén is megfigyelhető, hogy inkább Lukács marxista fordulatát követő korszakaira összpontosítanak. (Lásd például Hermann István: Lukács György élete, 1985.) Természetesen több magától értetődő érv is felhozható arra vonatkozóan, hogy ez miért alakult így, miközben úgy vélem, legalább ennyi érv szólhat a fiatalkori életmü hangsúlyozása és bővebb tárgyalása mellett is. Vannak olyan Lukács életét és munkásságát taglaló könyvek, amelyek Lukács fiatalkori életművére koncentrálnak (lásd Bendl Júlia: Lukács György élete a századfordulótól 1908-ig, 1994; Lendvai L. Ferenc: A fiatal Lukács - Útja Marxhoz, 2008), de vannak olyanok is, amelyek a marxista életművet, s ennek az 1945 utáni szakaszát állítják előtérbe (lásd például Zoltai Dénes: Egy írástudó visszatér, 1985). Fekete Éva könyve mindezekkel szemben helyezhető el: monográfiája Lukács György egész életének és munkásságának bemutatását nyújtja, és ami talán még hangsúlyosabb: a kötetben remek arányban oszlik meg a fiatalkori és a marxista életmü tárgyalása, oly módon, hogy ez nem jelenti egyik rész háttérbe szorítását sem a másikkal szemben.

A monográfia egyik legnagyobb erénye, hogy Fekete Éva kitűnő érzékkel kezeli az arányokat az életrajzi adalékok, valamint Lukács konkrét müveinek ismertetése és jellemzése között. Ennek köszönhetően a könyv bőven túlmutat egy egyszerü Lukács-életrajzon, bár ki kell mondanunk, hogy Fekete remekül használja a ránk maradt forrásokat - többek között Lukács kortársaival és barátaival folytatott, szerteágazó levelezését -, és az életrajzi mozzanatok alapos, finom, véletlenül sem túlzó bemutatásával egy olyan Lukács-portrét vázol, amely valóban hozzásegítheti az olvasót az életmú egyes részeinek alapos, részletekbe menő tanulmányozásához. Az életrajzi mozzanatok kronológiai sorban történő ismertetése tehát egyúttal megágyaz Lukács esztétikai, filozófiai munkásságának bemutatásához. A szerző egy monográfia terjedelmi lehetőségeihez mérten megvilágító és precíz módon tárgyalja, s értelmezi a filozófus hangsúlyosabb könyveit, esszéit, publicisztikáit. Ezen a helyen külön szeretném kiemelni a Heidelbergi müvészetfilozófiáról és esztétikáról (110-113.), illetve A regény 
elméletéről (120-125.) szóló részeket, amelyek több szempontból is kiemelkednek a monográfiában elemzett Lukács-mủvek közül. Egyrészröl tudjuk, hogy Fekete Éva és Karádi Éva voltak azok, akik elöször tanulmányozhatták Lukács Heidelbergből elökerült bőröndjének tartalmát, amely több fiatalkori munkája mellett az előbbi két mü kéziratát is tartalmazta. A bőrönd a monográfia születése tájékán került Fekete Évához, aki hihetetlen tempóban, nagy alapossággal dolgozta fel annak tartalmát, habár az említett müvek vizsgálata külön-külön is óriási munkát igényel. Ugyanakkor az általam kiemelt részek (110-113. és 120-125.) jól példázzák azt a módszert is, amelyet a szerző a kötet számos pontján alkalmaz: a művek tárgyalásakor Fekete Éva nem elégszik meg a felszínes, a mủvek primer tartalmának bemutatásával, hanem a legtöbb esetben igyekszik azokat eszme- és hatástörténeti, valamint egyéb életrajzi adalékokkal még inkább kontextualizálni és árnyalni. A két szálat összekötve így egészen pontos képet kaphatunk arról, hogy mik voltak azok az életrajzi körülmények, amelyek potenciálisan befolyásolták, alakították Lukács György gondolkodását, hogy a filozófusra mely időpillanatban kik gyakorolták a legnagyobb szellemi befolyást, valamint a levelezés alapján az is feltárul, hogy mely kortársai miként járultak hozzá beszélgetésekkel, tanácsokkal, és észrevételekkel a filozófus gondolatainak csiszolódásához, alakulásához.

A könyvben hangsúlyos szerepet kapnak a korrajzok (a kortörténeti vázlatok), amelyek legalább két szempontból is a kötet integráns részét képezik. Egyfelől gyakran megvilágító erejüek, ami Lukács cselekedeteinek motivációit, elvi elköteleződéseinek alakulását és a kortársak Lukácshoz való viszonyulását illeti. A korszakok rövid, orientáló jellemzései rendszerint messze túllépnek a történeti események puszta ismertetésein. Másfelől az adott kor szellemi életének bemutatása azt a célt is szolgálja, hogy rávilágítson Lukács különböző közegekben (például Társadalomtudományi Társaság, Galilei Kör, Vasárnapi Kör, Magyar Kommunista Párt) betöltött szerepére, illetve az azokhoz való viszonyára. Ezek alapján egyre erősebben érezzük, hogy Lukács - a maga szellemi teljesítményének és súlyának köszönhetően - már egészen fiatal korától kezdve megkerülhetetlen figurája volt a magyar szellemi életnek, és cikkeivel, előadásaival tevőlegesen is részt vállalt annak alakításában.

A kötet implicit módon ugyan, de állást foglal abban az izgalmas kérdésben, amely újra és újra felmerül a Lukács-kutatók körében: jelesül abban, hogy Lukács életmüve koherensnek tekinthető-e, vagy sem. Vagy a másik oldalról tekintve: beszélhetünk-e radikális gondolati törésről Lukács életmüvében? Vajon Lukács marxizmus felé fordulására olyan módon kell tekintenünk, amely nem következik egyenesen fiatalkori munkásságából, vagy ezzel szemben inkább úgy kellene Lukács gondolkodásának ívét értelmeznünk, mint amelyet egy alapvető folytonosság jellemez? Úgy vélem, Fekete Éva az utóbbi mellett foglal állást; ezt az állítást két fontos szempont kiemelésével támasztom alá. (1) A fiatal Lukács 
érdeklődésének középpontjában sokáig a „drámai müfaj esztétikai problémái” (51.) álltak. Fekete kiemeli, hogy a (dráma)elméleti érdeklődése mellett Lukácsnak erős késztetése volt arra, hogy tevőlegesen is részt vegyen különféle színházi munkákban. S ebből már következik: „Lukács karakterének mindvégig lényegi jellemzője marad: a teoretikus tevékenység mellett, azzal együtt, a gyakorlati mozgalomban való aktív részvétel" (52.). Ezzel azt állítva, hogy az elmélet és gyakorlat egységére való törekvés már a fiatal Lukács számára is nagyon fontos motívum volt. (2) Lukács gondolkodását alapjaiban áthatotta az etika, illetve mindvégig mereven elutasította az elvek relativizmusát. Természetesen ezek nem olyan szempontok, amelyek alapján azt állíthatnánk, hogy Lukács elött nem állt más út, és a marxista fordulata elkerülhetetlen volt. Csupán annyit mondhatunk, hogy koherensen képviselhető az az álláspont, miszerint Lukács fiatalkori gondolatvilágában több olyan motívum, illetve elvi elköteleződés is található, amelyek fényében nem kelthet akkora megrökönyödést, hogy Lukács, élete egy pontján a marxizmus felé fordul.

2021-ben, Lukács György halálának 50. évfordulója alkalmából számos megemlékezésre került sor: többek között kerekasztal-beszélgetéseket, konferenciákat rendeztek, cikksorozatokat szenteltek a filozófus életének és munkásságának bemutatására, itthon és külföldön egyaránt. Ebbe a sorba jól illeszkedik Fekete Éva monográfiája, amely ennyi év távlatából is képes rámutatni Lukács György életművének jelentőségére. Azt gondolom, a monográfia megjelenésével egy olyan hiánypótló mü látott napvilágot, amelyet nem csupán a Lukács-kutatók forgathatnak nagy haszonnal, hanem mindenki, aki a magyar eszmetörténet, irodalomtörténet és filozófia iránt érdeklődik.

(Fekete Éva: Lukács György. Késleltetett életrajz. Budapest: Kalligram Kiadó, 2021, 399 o.)

Daradics Boglárka egyetemi hallgató, Pécsi Tudományegyetem 